\title{
The Relationship Between Surgeons Communication and Patients Understanding in Jemursari Islamic Hospital Surabaya
}

\author{
Ega Widhatama ${ }^{1}$, Dayu Satriya Wibawa ${ }^{2}$, Mustika Chasanatusy Syarifah ${ }^{3}$ \\ ${ }^{1}$ Undergraduate Student of Faculty of Medicine, Universitas Nahdlatul Ulama Surabaya \\ ${ }^{2}$ Head of Departement of Surgery, Jemursari Islamic Hospital, Surabaya \\ ${ }^{3}$ Head of Bioethics and Islamic Medicine Unit, Faculty of Medicine, Universitas Nahdlatul Ulama Surabaya \\ Corresponding author: egawidhatama26@gmail.com,mustika4n6@unusa.ac.id
}

\begin{tabular}{|c|c|}
\hline ARTICLE INFO & ABSTRACT \\
\hline $\begin{array}{l}\text { Submission: } \\
\text { November, } 2^{\text {nd }} 2020 \\
\text { Review: } \\
\text { December, } 15^{\text {th }} 2020 \\
\text { Publish: } \\
\text { December, } 30^{\text {th }} 2020\end{array}$ & $\begin{array}{l}\text { Communication is a human activity to be able to understand a message } \\
\text { between communicators and communicants. Ordinary communication } \\
\text { ends with a result called the communication effect. Communication } \\
\text { usually occurs with the same meaning in a conversation. Understanding } \\
\text { can be defined as the ability to be able to correctly explain the object to be } \\
\text { known, and be able to interpret the material correctly. This study aims to } \\
\text { determine the relationship between surgeon communication and patient } \\
\text { understanding in the hospitalized surgery room at Jemursari Islamic } \\
\text { Hospital Surabaya. This research uses a consecutive sampling technique } \\
\text { based on sample criteria. The population was all surgical patients who } \\
\text { were going to perform surgery and samples were obtained according to } \\
\text { the inclusion and exclusion criteria. The sample size is } 65 \text { samples and the } \\
\text { research instrument was a questionnaire. The results of this study were } \\
\text { obtained ( } 36 \% \text { ) respondents communicated ineffectively and (64\%) } \\
\text { communicated effectively. Besides that, ( } 45 \%) \text { respondents did not } \\
\text { understand what the doctor explained, and (55\%) understood what was } \\
\text { explained. Analysis using test Chi- Square obtained a very significant } \\
\text { relationship between surgeon communication with patient understanding } \\
\text { with p-value }=0.000 \text {. }\end{array}$ \\
\hline
\end{tabular}

\section{Introduction}

Doctor-patient communication is one of the most important things in the treatment process in the hospital. Effective communication between doctors and patients is very good at reducing the number of complaints from patients. But not all doctors can communicate well with their patients. Lots of patients complain about their doctors not because of their abilities but because of their lack of attention to patients (Sikumbang, 2017).
Patients feel they do not understand what the doctor means. Also, some doctors do not have much time to explain the disease because there are too many patients. Finally, some patients flocked to take medication abroad. Based on the results of the Indonesian medical council, it shows that doctors in Indonesia have very little to communicate with. Then in modern times, doctors are also very preoccupied with entering data into a computer where doctors are not completely 
focused on their patients but are busy entering data into the computer. (Fourianalistyawati, 2015).

The misunderstanding of doctor-patient communication is often because the patient has surrendered all his fate to the doctor or hospital. The most common cause of misunderstanding by doctors and patients is that doctors have not communicated well with their patients. Because in the eyes of patients, doctors have been considered by patients as "gods of savior" so that they have the highest position. This position causes obstacles that create misunderstanding of communication (Alfitri, 2006).

Doctors inform a patient's illness by using informed consent. The most common complaint felt by patients lies in the lack of communication between doctors and patients. The patient desperately needs information about the diagnosis, medical procedures, the course of the disease. Patient rights to know everything the doctor will do for the treatment. In this way, doctors and patients can create good communication (Alfitri, 2006).

A good relationship between a patient and a doctor will establish good communication to increase trust. The doctor will respond if the patient responds very well to the information that has been conveyed. There are also doctors who have conveyed it well, but the patient does not understand what the doctor means because the patient's knowledge is low / or because the doctor also uses the medical language. So between doctors and patients must have good communication (Fouriana listyawati, 2015).

\section{Method}

The type of research used in this research is observational analytic. The analytic is the researcher wants to know what certain situations or conditions occur or what influences the occurrence of something. The design of this study is a cross-sectional approach, namely research to find the relationship between the independent variable and the dependent variable by taking momentary measurements. This study used a crosssectional study because it connected two variables between the communication between doctors and surgical patients using data collection. The research instruments were obtained from patients who were about to perform surgery in the Jemursari Hospital Surabaya inpatient room.

The sample used in this study is primary data. In the form of giving a questionnaire to surgical patients.

\section{Results}

All data in this study are primary data obtained from the azzahra room 2 of the Jemursari Hospital. This study used 65 samples of patients.

\section{A. Identification of Surgeon Communication in Jemursari Islamic Hospital}

\section{The Frequency of Surgeons Communication}

Frequency and the percentage of respondent characteristics based on surgeons communication in Jemursari Islamic Hospital. 


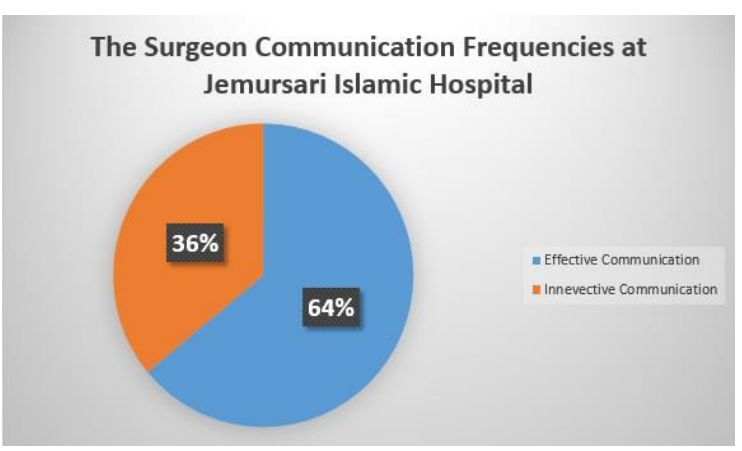

Figure 1. The frequency of surgeons communication.

Based on figure 1 shows that the respondents (64\%) communicate effectively.

\section{The Frequency of Patients Understanding.}

Frequency and percentage of respondent characteristics based on patients understanding in hospitalized surgery room.

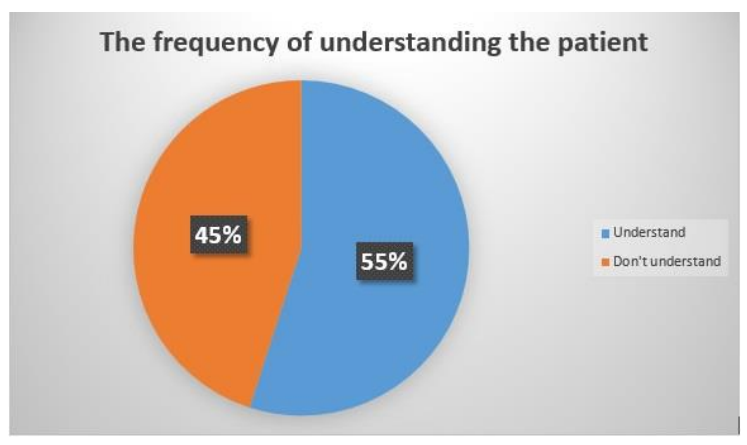

Figure 2. The frequency of understanding the patient

The figure 2 shows that respondents $(55 \%)$ understand the doctor's explanation.

\section{Respondents Frequency Based on Age}

Data on the results of filling out the questionnaire Frequency and percentage of respondent characteristics based on age were obtained during the table study.

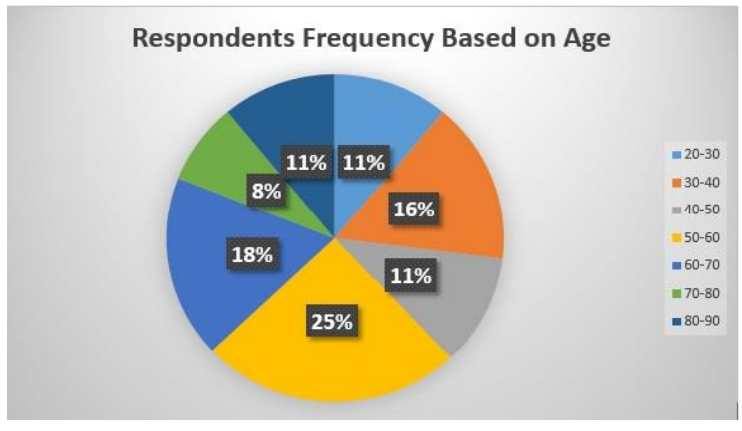

Figure 3. The frequency based on age

The figure 3 shows that most respondents (25\%) have an age of $50-60$ years.

\section{Respondent Frequency Based on Gender}

The frequency and percentage of respondent characteristics based on gender were obtained during the table study.

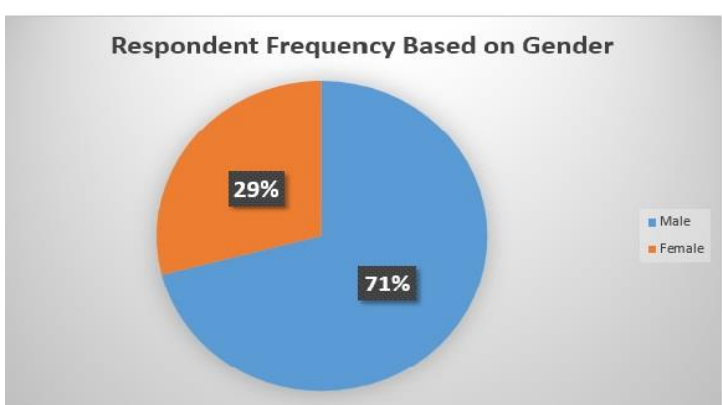

Figure 4. The frequency based on gender

Based on figure 4 shows that most of the respondents (71\%) are male.

\section{Response Frequency Based on Education}

The frequency and percentage of respondents based on education obtained during the research table

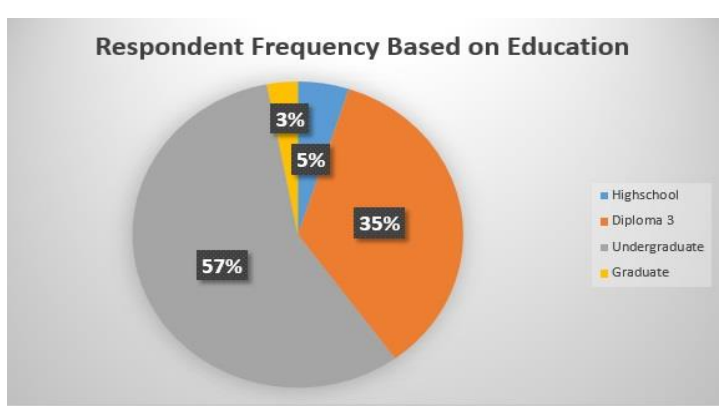

Figure 5. The frequency based on education 
Based on the figure 5 shows that most of the respondents (57\%) have undergraduate education.

\section{Analysis of The Relationship Between Surgeons Communication and Patients Understanding}

The analysis of the relationship between the surgeon communication and the incidence of understanding the patient observed by the researcher is as shown in the table.

Table 1. Correlation surgeons communication and level of patients understanding

\begin{tabular}{|c|c|c|c|c|c|c|c|}
\hline \multirow{3}{*}{$\begin{array}{c}\text { Doctor's } \\
\text { Communic } \\
\text { ation Level }\end{array}$} & \multicolumn{4}{|c|}{$\begin{array}{l}\text { Frequency of } \\
\text { understanding patient }\end{array}$} & & & \multirow{3}{*}{$\begin{array}{c}P \\
\text { Value }\end{array}$} \\
\hline & \multicolumn{2}{|c|}{ Effective } & \multicolumn{2}{|c|}{ Ineffective } & & & \\
\hline & $\mathrm{n}$ & $\%$ & $\mathrm{n}$ & $\%$ & $\mathrm{~N}$ & $\%$ & \\
\hline Effective & 32 & 88.9 & 9 & 31 & 41 & 63.1 & \\
\hline Ineffective & 4 & 11.1 & 20 & 69 & 24 & 36,9 & 0,000 \\
\hline Total & 36 & 100 & 29 & 100 & 65 & 100 & \\
\hline
\end{tabular}

Table 1 shows that the percentage of respondents with effective communication is higher than ineffective communication. The results of this data analysis used the test chi-square obtained $\mathrm{p}$-value $=0.000$, it can be concluded that there is a relationship between doctor communication with patient understanding.

\section{Discussion}

This study aims to determine the relationship between surgeon communication with patient understandability in the surgical inpatient room of Jemursari Islamic Hospital Surabaya. The discussion of the results of the data analysis of the research variables is explained as follows.

\section{Doctors Communication}

A doctor's communication is one of the most important moments in a patient's treatment. Doctors have a legitimate power because it is very easy to influence patients because what doctors say is more effective and can be well received by their patients. Communication here is divided into two, namely verbal and nonverbal. Where verbal communication is communication that we always say, while nonverbal is everything that has been conveyed by someone to another. In communicating with patients, doctors must apply communication techniques, namely giving greetings, asking questions, giving assistance, giving explanations, returning control. (Sukardi et al., 2008)

Based on the research that has been done, it states that $(36 \%)$ of respondents the communication is not effective. Some of the reasons for the ineffectiveness of the communication are because the doctors here have many patients which result in not being able to have enough time to explain to their patients. Then besides time, some doctors have not explained the procedure to be performed. Some doctors also have not used technology such as (audio-visual, pictures) in conveying to patients the patient's diagnosis, the questionnaire also explains the risk of action, many patients do not understand because the patient's condition is in pain. Almost all respondents (64\%) have communicated effectively. This is supported by the results of research conducted about the relationship between effective doctor-patient communication with the level of anxiety in preoperative patients, it was found that $(52 \%)$ doctors performed effective communication, which meant that there was a relationship between doctor-patient communication and anxiety levels. (Laksmi Pratita, Sis Indrawanto, and Handaja, 2017). 


\section{Patient Understanding}

Understanding is the ability to correctly explain the object to be known and can interpret the material correctly. Then the first indicator about the doctor's explanation, to find out whether the patient understands or not, namely being able to explain, conclude, predict. In addition, there are also factors that can influence this understanding, namely age, experience, gender, education, occupation, sociocultural and economic factors. (Notoatmodjo, 2010).

Based on the research that has been done, it states that $(45 \%)$ respondents do not understand the doctor's explanation. Some of the causes of not understanding patients are that many doctors still use medical language that is difficult for patients to understand. In addition, patients who are in pain have difficulty understanding the doctor's explanation, then education is an important factor in understanding doctor-patient communication were in this study (5\%) high school education, (35\%) D3, (57\%) S1 and (57\%) $3 \%) \mathrm{S} 2$ were when the research took place showed that SMA and D3 education got a lot less from the doctor's explanation which resulted in a lack of understanding of the communication because the doctor did not understand a broad picture of the diagnosis, when using the media (tab, audiovisual) the patient may understand better. In addition, age is also an influence on patient understanding which in this study also (25\%) patients aged 50-60 years. In my research, some patients have experienced hearing loss and are in pain due to the disease suffered by these patients. Therefore, the patient does not feel that he understands what the doctor explains. Almost all respondents (55\%) understood what was explained. The results of research conducted by In my research, some patients have experienced hearing loss and are in pain due to the disease suffered by these patients. Therefore, the patient does not feel that he understands what the doctor explains. Almost all respondents (55\%) understood what was the doctor explained. The results of research conducted by In my research, some patients have experienced hearing loss and are in pain due to the disease suffered by these patients. Therefore, the patient does not feel that he understands what the doctor explains. Almost all respondents $(55 \%)$ understood what was explained. The results of research conducted by the relationship between doctor-patient communication with the level of medical understanding of the patient's eye polyclinic hospital prof. Mulyanto University of Mataram, West Nusa Tenggara, the results obtained $(75 \%)$ of respondents understand the doctor's explanation, which means there is a positive and strong relationship between the patient's doctor's communication with the patient's level of understanding. (Dewi et al., 2017)

\section{Relationship Between Surgeons Communication and Patients Understanding}

Communication techniques relate to understanding the patient because of the key importance in medicine. With good communication, the doctor can listen to the patient. Communication that is often used by doctors is to use verbal communication which we always say. Where the patient can understand this, we can see from how the patient can conclude what the doctor has tried to do well. The factors that can influence understanding include age, 
gender, and education. The doctor's steps when conveying to the patient must include greeting, asking the patient, providing information after conducting the examination, and explaining in detail in order to create comfort for the patient. (Susanto, 2017) (Dewi et al., 2017).

In this study, the Chi-Square Test statistical test using the SPSS statistical application showed a value ( $\mathrm{p}$-value $=$ 0.000), which means that there is a very significant relationship between doctor's communication techniques and patient understanding. This is supported by the results of previous research conducted by (Dewi et al., 2017) concerning the relationship of doctor-patient communication with the level of medical understanding of the eye polyclinic hospital prof. Mulyanto Mataram University, West Nusa Tenggara obtained a $\mathrm{p}$-value of 0,000 . The correlation value $\mathrm{r}=$ 0.630 , which means that there is a positive and strong relationship between the patient doctor's communication with the patient's level of understanding.

\section{Conclusion}

Based on the result of this research. It was concluded that there were 42 respondents (64\%) who communicated effectively, 23 respondents $(35 \%)$ did not communicate effectively. In addition, there were 36 respondents $(55 \%)$ who understood the explanation, 29 respondents $(45 \%)$ did not understand the explanation. Between the two, there is a very significant relationship between surgeon communication techniques and patient understanding in the surgical inpatient room of RSI Jemursari Surabaya.

\section{References}

Alfitri, 2006. Komunikasi Dokter-Pasien. Mediator - Jurnal Komunikasi (Bandung),7(1), pp.15-26.

Caropeboka, R.M., 2017. Konsep dan Aplikasi Ilmu Komunikasi. Yogyakarta.

Dewi, E.S., Ninstyastuti, I.K., Prihatina, L.M. and Nurbaiti, L., 2017. Hubungan Komunikasi Dokter-Pasien dengan Tingkat Pemahaman Medis Pasien Poliklinik Mata Rumah Sakit prof . Mulyanto Universitas. 7(3), pp.1-6.

Fourianalistyawati, E., 2015. Komunikasi Yang Relevan Dan Efektif Antara Dokter Dan Pasien. Journal Psikogenesis, [online] 1(1), pp.82-87. Available at: <http://academic journal.yarsi.ac.id/index.php/JurnalOnline Psikogenesis/article/view/37/pdf

Ganiem, leila mona, 2018.Komunikasi Kedokteran Konteks Teoretis dan Praktis. Depok: Prenadamedia Group.

Indonesia, M.K., 2017. Analisis Faktor Faktor yang Mempengaruhi Pemahaman Pasien terhadap Informed Consent di Rumah Sakit. 5.

Laksmi Pratita, A., Sis Indrawanto, I. and Handaja, D., 2017. Hubungan Antara Komunikasi Efektif Dokter-Pasien Dengan Tingkat Kecemasan Pada Pasien Preoperasi. Saintika Medika, 10(2), p.93.

Muhit, A. and Siyoto, S., 2018. Aplikasi Komunikasi Terapeutik Nursing \& Health. Yogyakarta.

Pakendek, A., 2010. Informed Consent dalam Pelayanan Kesehatan. Al Ihkam, V(2), pp.309-318.

Panuju, R., 2018. Pengantar Studi (Ilmu) Komunikasi komunikasi Sebagai Kegiatan Komunikasi Sebagai Ilmu. Jakarta: Kencana.

Rustan, A.S. and Hakki, N., 2017. Pengantar Ilmu Komunikasi. Yogyakarta: CV Budi Utama. 
Sikumbang, A.T., 2017. TEORI KOMUNIKASI (Pendekatan, Kerangka Analisis dan Perspektif). analytica islamica, 6, pp.77-85.

Sukardi, E., Soetjiningsih, Kandera, I.W., Parwati, T., Astawa, P. and Marheni, A., 2008. Modul Komunikasi Pasien Dokter. Jakarta: Penerbit Buku Kedokteran EGC.

Suprapto, T., 2009. Pengantar Teori \& Manajemen Komunikasi. Yogyakarta.

Susanto, dewangga primananda, 2017. Analisis Faktor-Faktor yang Mempengaruhi Pemahaman Pasien terhadap Informed Consent di Rumah Sakit. dewa, 5.

Syahdrajat, D.T., 2018. Panduan Penelitian Untuk Skripsi kedokteran \& Kesehatan. Pedhe offset.

Wiryanyo, 2004. Pengantar Ilmu Komunikasi. Jakarta: PT Grasindo. 